\title{
SCREENING BY TRANSCRANIAL DOPPLER ULTRASONOGRAPHY OF MIDDLE CEREBRAL ARTERY IN CHILDREN WITH SICKLE CELL DISEASE
}

\author{
Kanaka Durga Prasad Bhamidipaty1, Madhavi Chamarthi², Pravallika Isireddy ${ }^{3}$ \\ ${ }_{1}^{1}$ Associate Professor, Department of Radiodiagnosis, GIMSR, Visakhapatnam. \\ 2Professor, Department of Radiodiagnosis, MIMS, Nellimarla. \\ ${ }^{3}$ Resident, Department of Radiodiagnosis, GIMSR, Visakhapatnam.
}

\section{BACKGROUND}

ABSTRACT

Sickle cell disease is a common haematological disorder. The prevalence of this disease varies from $2 \%$ to $34 \%$ in our country. There is neovascularisation and sickle red cell induced inflammation of the endothelium of vessels resulting in narrowing of the lumen of vessels. This occlusive vasculopathy results in increased blood flow velocities in major intracranial vessels in children with sickle cell disease. This predisposes them to ischaemic and haemorrhagic infarcts in brain resulting in strokes. TCD (Transcranial Doppler) is a useful radiological tool to screen the children with increased mean blood flow velocities in distal internal carotid artery and proximal middle cerebral artery.

This study was aimed to assess the blood flow velocities in left and right middle cerebral arteries of children with sickle cell disease and to compare these velocities with a control group of normal children, matching their sex and age profile.

\section{MATERIALS AND METHODS}

This is a hospital-based comparative study done at Gitam's Institute of Medical Sciences and Research, Visakhapatnam, Andhra Pradesh and Maharajah's Institute of Medical Sciences, Nellimarla, Vizianagaram district, Andhra Pradesh. Purposive and convenient sampling technique was used for data collection. The study was done on 20 children in whom sickle cell disease was confirmed by electrophoresis and on same number of age and sex matched controls. The velocities thus obtained were stratified according to the classification based on STOP (Stroke Prevention Trial 1) study and analysed. Statistical analysis of the data was done by using SPSS software version 16. A p value of less than 0.05 was taken as significant.

\section{RESULTS}

Mean blood flow velocities in middle cerebral arteries were significantly higher in our cases when compared to control group. It was observed that 17 out of the 20 children with sickle cell disease had elevated velocities in the range of $170-199 \mathrm{~cm} / \mathrm{s}, 1 \mathrm{child}$ had a velocity of less than $170 \mathrm{~cm} / \mathrm{s}$ and 2 children had mean velocities of more than $200 \mathrm{~cm} / \mathrm{s}$.

\section{CONCLUSION}

Transcranial Doppler sonography is an inexpensive, non-invasive imaging modality for screening the patients with sickle cell disease, to detect children who are at risk for stroke.

\section{KEYWORDS}

Sickle Cell Disease, Transcranial Doppler, Stroke, STOP Trial.

HOW TO CITE THIS ARTICLE: Bhamidipaty KDP, Chamarthi M, Isireddy P. Screening by transcranial Doppler ultrasonography of middle cerebral artery in children with sickle cell disease. J. Evolution Med. Dent. Sci. 2018;7(05):679-682, DOI: $10.14260 /$ jemds/2018/154

\section{BACKGROUND}

Sickle cell disease (SCD) is the most common haematological disorder with autosomal recessive inheritance. The prevalence of this disease varies from $2 \%$ to $34 \%$ in our country. ${ }^{1}$ Children with SCD have chronic haemolysis resulting in low haemoglobin content. There is neovascularisation and sickle red cell induced inflammation of the endothelium of vessels resulting in narrowing of the lumen of vessels. This occlusive vasculopathy involving the major intracranial vessels predisposes the children with SCD to ischaemic and haemorrhagic infarcts in brain. ${ }^{2}$ The neurological manifestations in SCD range from minor

'Financial or Other Competing Interest': None.

Submission 27-12-2017, Peer Review 15-01-2018,

Acceptance 18-01-2018, Published 29-01-2018.

Corresponding Author:

Madhavi Chamarthi,

Department of Radiodiagnosis,

MIMS, Nellimarla.

E-mail: chmadhavi_80@yahoo.com

DOI: $10.14260 /$ jemds/2018/154

complaints like headache to more serious problems such as stroke. ${ }^{3} 11 \%$ of patients with SCD may present with stroke by the age of 20 years. Brain infarction in patients with SCD is most common in those aged between 2 and 5 years and is associated with homozygous $\mathrm{HbS}$ phenotype. 4 Children with increased blood flow velocity in distal internal carotid or proximal middle cerebral artery are at highest risk of stroke. ${ }^{5}$ It is now established that the blood flow velocities in the major intracranial vessels can be evaluated by Transcranial Doppler ultrasonography (TCD). ${ }^{5}$

TCD was first used clinically by Aaslid in $1982 .{ }^{6}$ It is a non-invasive, inexpensive and convenient test to measure the blood flow velocities in the basal arteries of the brain. It can also be used to monitor the changes in velocities in response to intervention. Haematocrit and viscosity are inversely related to cerebral blood flow velocity.7,8 Blood flow velocities increase by nearly $20 \%$ with a drop in haematocrit from $40 \%-30 \% .{ }^{9}$ An increase in the mean velocity of more than $200 \mathrm{~cm} / \mathrm{s}$ in internal carotid artery and middle cerebral artery (MCA) on TCD have been shown to be associated with increased risk of ischaemic stroke in children. ${ }^{10}$ Children with 
Sickle cell anaemia have a significant drop in their mean flow velocities after a blood transfusion. ${ }^{10}$

In the STOP trial, (Stroke Prevention Trial I) children between 2 to 16 years of age with no history of stroke and MCA velocity of $200 \mathrm{~cm} / \mathrm{s}$ were randomly allocated to standard care or to periodic blood transfusion therapy to keep the $\mathrm{HbS}$ concentration to less than $30 \%$ of total haemoglobin. They concluded that blood transfusion based on mean flow velocity resulted in $92 \%$ reduction of stroke risk. ${ }^{10}$ A five-fold decrease in the rate of first stroke was observed in children with SCD. ${ }^{10}$ In another study by Enninful-Eghan $\mathrm{H}$ et al, the incidence of stroke declined 10 folds following TCD screening and prophylactic transfusions over a period of 8 years. ${ }^{11}$ The sickle gene is prevalent among many tribal population groups in India in Madhya Pradesh, Maharashtra, Odisha, Gujarat, Rajasthan, Jharkhand, Chhattisgarh, Andhra Pradesh, West Bengal and Karnataka. ${ }^{12}$

A study by Dipty Jain et al from central India reported a very high incidence of significant clinical events in children with SCD, with $30 \%$ of the patients having severe disease. This study reported that $62 \%$ of blood transfusions were needed when the age of the patients was less than 5 years. TCD screening coupled with prophylactic transfusions helps to reduce overt stroke in children with SCD. So, the present study was undertaken with the aim of assessing the blood flow velocities in right and left middle cerebral artery of children with SCD and to compare them against a control group of children matching the age and sex.

\section{MATERIALS AND METHODS}

This is a hospital-based comparative study. The study was conducted at Gitam's Institute of Medical Science and Research, Visakhapatnam, Andhra Pradesh and Maharajah's Institute of Medical Sciences, Nellimarla, Vizianagaram district, Andhra Pradesh. Both are tertiary level referral hospitals. This study was conducted from October 2015 to September 2017, following approval of Institutional Ethics Committee.

A purposive and convenient sampling technique was used for the data collection from the study population who were conveniently available (those who satisfy the inclusion and exclusion criteria) to participate in the study.

\section{Inclusion Criteria}

Children with electrophoresis confirmed SCD in the age group of 2 to 15 years were included as cases in the study. An equal number of age and sex matched healthy children with haemoglobin in the normal range attending the hospital for unrelated ailments were taken as controls.

\section{Exclusion Criteria}

Children with fever, sickle cell crisis, other associated chronic illnesses, history of blood transfusions in last 6 months, any clinical event in the last 30 days, history of overt stroke, any neurological deficits and children on treatment with hydroxyurea.

The procedure was performed after it was explained to the children and informed consent from the parents or guardian was obtained. Detailed history of cerebrovascular accident or any neurological deficit, bone pain, sickle crisis or previous history of blood transfusion was taken and the details of treatment were documented.
TCD study was done using a $2 \mathrm{MHz}$ probe using a transtemporal approach by evaluating right and left middle cerebral arteries. The procedure was performed when the child was calm. Care was taken to see that they did not move their legs, laugh or sleep during the procedure, as that would alter the flow velocity patterns. Children with SCD were stratified based on the criteria used in STOP trial.13

\section{Criteria for Stratification}

- Normal: $<170 \mathrm{~cm} / \mathrm{s}$

- Conditional: $170-199 \mathrm{~cm} / \mathrm{s}$

- Higher/ abnormal: $>200 \mathrm{~cm} / \mathrm{s}$

- Time averaged mean of maximum velocities in MCA were obtained and details were tabulated.

\section{Statistical Analysis}

All the statistical analysis was performed by using Microsoft Excel and SPSS version 16. All quantitative variables were expressed as Mean \pm S.D. Student independent sample t-test was used for comparison between the two groups. P value of less than 0.05 was considered as statistically significant.

\section{RESULTS}

In the present study, male-to-female ratio is 13:7 and 14:6 in cases and controls respectively (Table 1). Mean age of the children was 6.55 and 6.70 years in cases and controls respectively (Table 2). Mean blood flow velocity in MCA in normal children varied between 50 to $80 \mathrm{~cm} / \mathrm{sec}$. Among the cases, one case had blood flow velocity of less than $170 \mathrm{~cm} / \mathrm{s}$, 2 cases had velocity of more than $200 \mathrm{~cm} / \mathrm{sec}$ and all the remaining children had flow velocities in the range of 170 to $199 \mathrm{~cm} / \mathrm{s}$ (Table 3). Two children who had mean velocities of more than $200 \mathrm{~cm} / \mathrm{s}$ were males aged 13 and 14 years respectively. They were further investigated by MRI Brain and MR Angiogram of intracranial blood vessels. Blood flow velocities in right and left MCA of 20 children with sickle cell disease were studied and were compared with the velocities of 20 normal children (Table 4 and 5). Mean blood flow velocities were significantly higher in cases when compared to controls in right and left middle cerebral arteries.

\begin{tabular}{|c|c|c|c|c|}
\hline & \multicolumn{2}{|c|}{$\begin{array}{c}\text { Children with Sickle } \\
\text { cell Anaemia n=20 Cases }\end{array}$} & $\begin{array}{c}\text { Normal Children } \\
\text { Controls }\end{array}$ \\
\hline Age Group & Male & Female & Male & Female \\
\hline$<5$ Years & 5 & 3 & 6 & 2 \\
\hline 5-10 Years & 6 & 2 & 5 & 3 \\
\hline 10-15 Years & 2 & 2 & 3 & 1 \\
\hline Total & \multicolumn{3}{|c|}{$\mathbf{2 0}$} & \multicolumn{2}{c|}{$\mathbf{2 0}$} \\
\hline Table 1. Distribution of Children based on Age and Sex \\
\hline
\end{tabular}

\begin{tabular}{|c|c|c|c|c|}
\hline \multirow{2}{*}{$\begin{array}{c}\text { Age in } \\
\text { Years }\end{array}$} & Group & $\mathbf{n}$ & Mean & Std. Deviation \\
\cline { 2 - 5 } & Cases & 20 & 6.55 & 3.734 \\
\cline { 2 - 5 } & Controls & 20 & 6.70 & 3.373 \\
\hline
\end{tabular}

Table 2. Comparison of the Mean Age of Children between Cases and Controls

\begin{tabular}{|c|c|c|}
\hline $\begin{array}{c}\text { Mean Blood Flow Velocity } \\
\text { Range in cm/s }\end{array}$ & $\begin{array}{c}\text { No. of Patients } \\
\mathbf{n = 2 0}\end{array}$ & $\mathbf{\%}$ \\
\hline$<170$ & 1 & $5 \%$ \\
\hline $170-199$ & 17 & $85 \%$ \\
\hline$>200$ & 2 & $10 \%$ \\
\hline
\end{tabular}

Table 3. Distribution of Cases based on Mean Blood Flow Velocity in MCA 


\begin{tabular}{|c|c|c|c|c|c|}
\hline \multirow{2}{*}{$\begin{array}{l}\text { Right } \\
\text { MCA }\end{array}$} & Group & n & Mean & Std. Deviation & P value \\
\cline { 2 - 5 } & Cases & 20 & 183.45 & 15.347 & \multirow{2}{*}{$0.000^{*}$} \\
\cline { 2 - 5 } & Controls & 20 & 66.55 & 8.775 & \\
\hline
\end{tabular}

Table 4. Comparison of Blood Flow Velocities in Right MCA

*Significant.

\begin{tabular}{|c|c|c|c|c|c|}
\hline \multirow{3}{*}{ Left } & Group & n & Mean & Std. Deviation & P value \\
\cline { 2 - 5 } MCA & Cases & 20 & 187.05 & 16.237 & \\
\cline { 2 - 5 } 0 & Controls & 20 & 70.40 & 7.563 & $0.000^{*}$ \\
\hline
\end{tabular}

Table 5. Comparison of Blood Flow Velocities in Left MCA *Significant.

\section{DISCUSSION}

The results of our study are comparable with the study of Lakkhar et al.14 Lakkhar et al in their study measured velocities in middle cerebral, posterior cerebral, common carotid, internal carotid, external carotid and vertebral arteries. However, we evaluated the flow velocities in MCA only. The prevalence of high flow velocities of more than 200 $\mathrm{cm} / \mathrm{s}$ in sicklers was $10 \%$ in our study, while the prevalence was $8 \%$ in the study by Lakkhar et al. MRI was performed on the two children with high flow velocities, but it did not reveal any changes of ischaemia and MRA did not reveal any focal stenotic segments. This suggests the probability of global ischaemia. In view of high flow velocities in MCA, these two children were advised further follow-up. However, in a study by Bernaudin $\mathrm{F}$ et al, silent infarcts were found on neuroimaging. ${ }^{15}$

A study by Minniti CP et al found that TCD was helpful in detecting a decrease in blood flow velocities following transfusion. ${ }^{16}$ Thus, TCD also has a role in monitoring the changes in blood flow velocities in response to interventions. We did not find any statistically significant difference between right and left MCA velocities, which is comparable with the study of Krejza et al. ${ }^{17}$ According to a study by Pegelow et al, it is recommended to advise a transcranial MRI for all sickle cell children with grossly elevated blood flow velocities as silent infarcts and recurrence of infarcts has been reported in $21 \%$ of these children. 18 Mazumdar et al suggested annual TCD until the age of 10 years and transfusion in high risk until the age of 18 years as the optimal stroke prevention strategy. 19

Though TCD is a good screening tool, it is highly operator dependant and there may be an inadequate acoustic window in $10 \%-15 \%$ of cases. ${ }^{20}$ Another limitation of TCD is that it provides an index of global rather than focal cerebral flow velocity. TCD should be avoided in children during acute illness, fever, hypoglycaemia, worsening anaemia as these conditions affect the flow velocities.

\section{CONCLUSION}

TCD is an inexpensive, well tolerated, well-accepted and noninvasive tool to screen the children with SCD who are at risk of stroke. In a resource poor country like India, TCD appears to be a valuable and feasible tool for screening children with sickle cell disease to detect the children at risk of stroke.

\section{ACKNOWLEDGEMENTS}

We would like to thank Dr. G. Indira, Mr. N. Lakshmana Rao and all the patients for their cooperation.

\section{REFERENCES}

[1] Jain D, Italia K, Sarathi V, et al. Sickle cell anaemia from central India: a retrospective analysis. Indian Pediatr 2012;49(11):911-3.

[2] Jordan LC, Casella JF, Debaun MR. Prospects for primary stroke prevention in children with sickle cell anaemia. Br J Haematol 2012;157(1):14-25.

[3] Brown RC. Common neurologic complications in sickle cell anaemia. In: Maria BL. edr. Current management in child neurology. $3^{\text {rd }}$ edn. London: BC Decker Inc., 2005:640-4.

[4] Mehtha SH, Adams RJ. Treatment and prevention of stroke in children with sickle cell disease. Current Treatment Options in Neurology 2006;8(6):503-12.

[5] Adams R, McKie V, Nichols F, et al. The use of transcranial Doppler ultrasonography to predict stroke in sickle cell disease. $\mathrm{N}$ Engl J Med 1992;326(9):605-10.

[6] Aaslid R, Markwalder TM, Nornes H. Non-invasive transcranial Doppler ultrasound recording of flow velocity in basal cerebral arteries. J Neurosurg 1982;57(6):769-74.

[7] Brass LM, Pavlakis SG, DeVivo D, et al. Transcranial Doppler measurements of the middle cerebral artery. Effect of hematocrit. Stroke 1988;19(12):1466-9.

[8] Fiemonte G, Spiriti AMA, Latagliata R, et al. Polycythaemia vera and cerebral blood flow: a preliminary study with TCD. J Intern Med 1993;234(6):599-602.

[9] Babikian VL, Weksler LR, Tade JF. Transcranial Doppler Ultrasonography. $2^{\text {nd }}$ edn. USA: ButterwarthHainemann 1999.

[10] Fullerton HJ, Adams RJ, Zhao S, et al. Declining stroke rates in California children with sickle cell disease. Blood 2004;104(2):336-9.

[11] Enninful-Eghan H, Moore RH, Ichord R, et al. TCD ultrasonography and prophylactic transfusion program is effective in preventing overt stroke in children with sickle cell disease. J Pediatric 2010;157(3):479-84.

[12] Colah RB, Mukherjee MB, Martin S, et al. Sickle cell disease in tribal population in India. IJMR 2015;141(5):509-15.

[13] Adams RJ, McKie VC, Hsu L, et al. Prevention of a first stroke by transfusion in children with sickle cell anemia and abnormal results of transcranial Doppler ultrasonography. N Engl J Med 1998;339(1):5-11.

[14] Lakhkar BB, Lakhkar BN, Vasvani P. Transcranial Doppler study among children with sickle cell anaemia vs normal children. J Nepal Paediatric Soc 2012;32(2):146-9.

[15] Bernaudin F, Verlhac S, Freard F, et al. Multicenter prospective study of children with sickle cell disease: radiographic and psychometric correlation. J Child Neurology 2000;15(5):333-43.

[16] Minniti CP, Gidvani VK, Bulas D, et al. TCD changes in children with sickle cell disease on transfusion therapy. J Paediatr Haematol Oncol 2004;26(10):62630 . 
[17] Krejza J, Chen R, Romanowicz G, et al. Sickle cell disease and TCD imaging: inter-hemispheric differences in blood flow Doppler parameters. Stroke 2011;42(1):81-6.

[18] Pegelow CH, Macklin EA, Moser FG, et al. Longitudinal changes in brain MRI findings in children with sickle cell disease. Blood 2002;99(8):3014-8.
[19] Mazumdar M, Heeney MM, Sox CM, et al. Preventing stroke among children with Sickle cell anaemia: an analysis of strategies that involve TCD testing and chronic transfusion. Paediatrics 2007;120(4):e110716.

[20] Purkayastha S, Sorond F. Transcranial Doppler ultrasound: technique and application. Semin Neurol 2012:32(4):411-20. 